\title{
The Potential for Greener Consumption: Some Insights from Malaysia
}

\author{
Syaidatina Akila Mohamad Azizan \\ Labuan School of International Business and Finance \\ Universiti Malaysia Sabah \\ E-mail: syaidatina_akila@yahoo.co.uk \\ Norazah Mohd Suki \\ Labuan School of International Business and Finance \\ Universiti Malaysia Sabah \\ E-mail: azahsuki@yahoo.com
}

Doi:10.5901/mjss.2014.v5n16p11

\section{Abstract}

Consumers' consumptions are the major component for the economy of a country. The main purpose of this study is to determine the factors that lead Malaysians towards their intention to purchase greener products. Self-administered questionnaires were distributed to a total of 431 respondents at several states in Malaysia including Sabah, Sarawak and Federal Territory of Labuan. Empirical results via multiple regressions indicate that Environmental Attitude is the most important factor for green purchase intention followed by Health Consciousness and Environmental Knowledge whereas Environmental Labelling was found to be insignificant. The study suggests that understanding of environmental problems is not enough without a positive behaviour towards preserving the environment. This study also identifies the needs to increase awareness about green labelling on the product.

Keywords: green purchasing; intention; consumer behaviour; labelling; hierarchical regressions; Malaysia;

\section{Introduction}

The Statistics Department of Malaysia (2013) noted that the total population in Malaysia in 2013 was 28 million with the average of household expenditure in average of 78.6 million ringgit from 2005 to 2013 (Tradingeconomics.com 2013). The household expenditures have indirectly become a social contribution whenever they make the purchasing. In the traditional way of purchasing, consumers will buy the best quality products that they can afford where people will normally choose the cheapest product, but only if they are confident that its 'utility' is as good as slightly more expensive options available (Beardshaw, 1992:59). Whereas, the price sensitive consumers are more concern with the quality and the ultimate value of environmental benefits (D'Souza 2004).

There are varieties of consumable product in the market. From food, clothing, electrical appliances, cosmetics, recycled paper, to detergents and soaps. It is the essentials for households. Greener products are made in a fairly acceptable way during the production process, and have lesser impact to the environment (Pickett-Baker \& Ozaki, 2008), works equally or better than conventional products, and because of those, it is considered worth a premium price (Ottman, 2011).

Even though green products need the support from consumers but creating meaningful progress towards sustainability requires more radical solutions than just development of new products substitutions among consumers (Peattie \& Peattie, 2008). Ethical consumption is an important element in educating consumers before they can advocate the role of green consumers; who not just literally recognize themselves as pro-environmental consumers but also act ethically in their purchasing. Furthermore, ethical consumerism is important to contribute to a more responsible purchasing and consumptions, thus it is important to convey and educate the consumers, companies and corporations about ethical consumerism, as the exposure on ethical purchasing is very limited (Ismail \& Panni, 2008). This study aims to determine the factors that lead Malaysians towards their intention to purchase greener products. 


\section{Literature Review}

Intention can be considered as an immediate antecedent of an actual behaviour and an indicator of how hard individuals are willing to try and an indicator of how much effort individuals are planning to exert in order to engage in a given behaviour. In general, the stronger the intentions to participate in a given behaviour, the greater the likelihood the particular behaviour will be performed. This study defines green purchase intention as a person's attention to look for more environmentally friendly or greener products (i.e. organic foods, chlorofluorocarbon (CFC) free aerosol, biodegradable soaps etc.) within a specified period of time and the probability that he or she will purchase the products.

\subsection{Health conciousness}

Health concern is one of the significant factors to be considered when consumer is dealing with purchasing decisions for the households. An individual with a positive belief on health is more concerned about their health, where they try to live in healthier lifestyle such as keeping healthy diets, exercising, and avoid smoking. Obesity is found as a significant health concern in Malaysia because of unhealthy food consumption and lack of physical activities (Tan, Dunn, Abdul Samad, \& Feisul, 2010). Psychologically, health consciousness guides people to engage in healthy behaviours (Becker, Maiman, Kirscht, Haefner \& Drachman, 1977). The first hypothesis is implies as follow:

$\mathrm{H}_{1}$ : Health consciousness has a positive influence towards consumers' intention to purchase greener product

\subsection{Environmental attitude}

Environmental attitude is related to the individual's value judgement of environmental protection (Lee, 2008). Although attitude was found significant in most studies (Kim \& Choi, 2005; Laroche, Bergeron \& Barbero-Forleo, 2001; Laskova, 2007; Sinnappan \& Rahman, 2011; Wahid, Rahbar \& Shyan, 2011), a recent study shows that attitude works in a twodimensional way (Wahid et al., 2011), where a consumers' environmental attitude was not just based on how they value the importance of protecting the environment but also the awareness on environmental problems. Consumers with this set of attitude and beliefs will relate environmental issues with their daily lives, work and family, as environmental issues evokes their positive feelings on greener products (Chen \& Chai, 2010). Thus, the following hypothesis is developed:

$\mathrm{H}_{2}$ : Environmental attitude has a positive influence towards consumers' intention to purchase greener product.

\subsection{Eco-labelling}

Eco-label was not much sensitized among consumers yet and had become understated. Rashid (2009) concluded that there is a need to increase the level of awareness on eco-labelling among Malaysian consumers as the higher level of eco-label awareness influence a strong relationship between attitude towards environmental protection and intention to purchase green products. Furthermore, eco-labelling is an important trademark for consumers not just to help them differentiate between conventional products and organic products (Rashid, 2009), but in fact, it is considered as a seal of approval, where the product label (i.e. specified logos or standards) is certified by trusted organisations and it increases consumers' trust (D'Souza, 2004). Labelling was indirectly a useful communication tool for marketers to consumers by stating a high standard of the product quality and assurance of its safety for their consumption as well as presumed to be safe to the environment. Thus, this study proposes that:

$\mathrm{H}_{3}$ : Eco-labelling has a positive influence towards consumers' intention to purchase greener product.

\subsection{Environmental knowledge}

Environmental knowledge evolves in two forms: (i) the extend that consumers need to be educated to understand the general impact of the product on the environment and, (ii) consumer knowledge in the product itself being produced in an environmental-friendly way (D'Souza, Taghian, \& Lamb, 2006). Haron, Paim, and Yahaya (2005) studied about Malaysians' environmental knowledge concluded that respondents have strong basic environmental knowledge, high ability to identify environmental problems in Malaysia, and high knowledge on recyclable items. Even though a consumer was highly knowledgeable about environmental issues, that does not provide an assurance that they will involve positively with green purchasing intention and behaviour (D'Souza et al., 2006; Laroche et al., 2001). Hence, it is posited that:

H4: Environmental knowledge has a positive influence towards consumers' intention to purchase greener product. 
Based on the above said review of literature, Figure 1 illustrates the proposed theoretical framework.

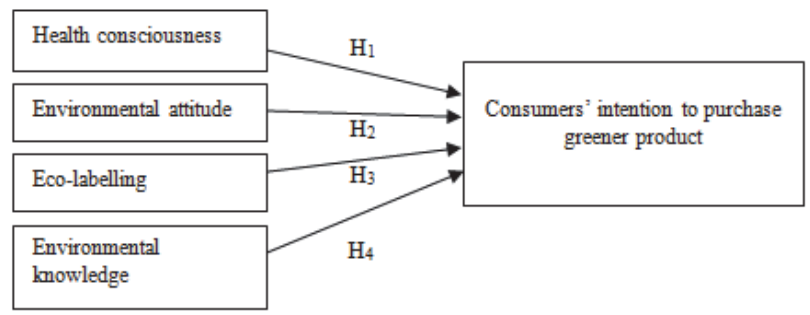

Figure 1. Proposed Theoretical Framework

\section{Research Methodology}

\subsection{Sampling procedures and data collections}

The "rule of thumb" for sample size is either; (1) Ten times the scale with the largest number of formative indicators (scales with reflective indicators can be ignored) or (2) Ten times the largest number of antecedent constructs leading to an endogenous construct (Cabrita \& Bontis, 2008). The current study applies the second criterion where there are four independent variables where 4 times 10 bring the total sample size to 40 . However, it is more adequate to have $50-500$ samples in a social science research (Sekaran, 2009). A total of 431 data were collected at the main cities of eight states in Malaysia namely: Kuala Lumpur, Selangor, Johor, Pahang, Penang, Sabah, Federal Territory of Labuan, and Sarawak as this study utilized stratified random sampling. The data were distributed via online survey and hard copies. The states chosen are the mixed of high and low density of population at the city of each, where Kuala Lumpur reported a 100 percent density and Pahang has the least density at 50.5 percent (Statistics Malaysia, 2010).

\subsection{Measurement of instruments}

The questionnaire was divided into six sections: Health consciousness (adapted from Shaharudin, Pani, Mansor, Elias, \& Sadek, 2010), Environmental attitude (adapted from Laroche et al., 2001; Kim \& Choi, 2005), Eco-labelling (adapted from Rashid, 2007), Environmental knowledge (adapted from Haron et al., 2005) and Green Purchase Intention (adapted from Chan \& Lau, 2000). This study utilized the eco-label logo from SIRIM in the research questionnaire in order to know their awareness, perception, and familiarity of the logo. A measurement of 5- to 7- point likert-scale (1=Completely disagree to $7=$ Completely agree) was appointed as it produces the same mean scores compare to 10 - point scale. None of the three formats is less desirable from the viewpoint of obtaining data that will be used for regression analysis. Kurtosis and skewness were likewise all very similar for each format. Therefore, either 5-, 7- or 10-point scales are all comparable for analytical tools (Dawes, 2008: 75).

\section{Data Analysis}

The results revealed that the samples of data were comprises of 189 male and 241 female with more than half of the respondents' age was between 20 to 29 years (63.7\%). The Malays dominated the race group with 287 respondents (66.7\%), 50 Chinese (11.6\%), and 9 Indians (2.1\%). Respondents' income was range from RM2001 to RM4000 due to the majority of them (49.5\%) has no fixed income as they are still pursuing their study in college either at undergraduate or postgraduate level, or just finished school.

\subsection{Factor analysis}

Exploratory Factor Analysis (EFA) was conducted to validate and simply reduces the data as well as it is an interdependence technique primarily used for data reduction and summarization as well as to identify underlying relationships (Hair, Lukas, Miller, Bush \& Ortinau, 2008). The results showed that Kaiser-Meyer-Olkin (KMO) measure of sampling adequacy was 0.839 which indicated sufficient inter-correlations among the factors; while, the Bartlett's Test of 
Sphericity was found significant (Chi square $=4466.383, p<0.01$ ). All items loadings must exceeded 0.50 whereby loadings below than 0.50 were excluded as suggested by Hair, Anderson, Tatham and Black (2010). Table 1 delineates that result of the exploratory factor analysis.

Table 1. Results of Factor Analysis

\begin{tabular}{|c|c|c|}
\hline Construct and Measures & Factor Loadings & Cronbach's Alpha \\
\hline \multicolumn{3}{|l|}{ Health consciousness } \\
\hline I take responsibility for the state of my health & 0.818 & \multirow{3}{*}{0.858} \\
\hline I consider myself very health conscious & 0.794 & \\
\hline I think that I take health into account a lot in my life & 0.790 & \\
\hline \multicolumn{3}{|l|}{ Environmental attitude } \\
\hline Recycling will reduce pollution. & 0.791 & \multirow{5}{*}{0.808} \\
\hline Recycling is important to save natural resources. & 0.789 & \\
\hline Recycling will save land that would be used as dumpsites. & 0.754 & \\
\hline I can protect the environment by buying products that are friendly to the environment & 0.632 & \\
\hline I feel I can help solve natural resource problems by conserving energy & 0.553 & \\
\hline \multicolumn{3}{|l|}{ Eco-labelling } \\
\hline The eco-label is easily recognizable for me. & 0.841 & \multirow{4}{*}{0.852} \\
\hline The logo is symbol of product reliability. & 0.816 & \\
\hline I am aware of the eco-label. & 0.781 & \\
\hline I believe the logo is truthful. & 0.743 & \\
\hline \multicolumn{3}{|l|}{ Environmental knowledge } \\
\hline Our country is faced with serious solid waste (garbage) and landfill problems & 0.702 & \multirow[t]{3}{*}{0.70} \\
\hline Unleaded petrol is better than leaded petrol as it is less harmful to the environment & 0.695 & \\
\hline Vehicles improperly maintained will cause pollution & 0.678 & \\
\hline \multicolumn{3}{|l|}{ Green purchase intention } \\
\hline I consider switching to other brands for ecological reasons. & 0.843 & \multirow{4}{*}{0.875} \\
\hline I intend to buy green products because they are less polluting. & 0.837 & \\
\hline I intend to switch to other brand for ecological reasons. & 0.808 & \\
\hline I consider buying green products because they are less polluting. & 0.797 & \\
\hline
\end{tabular}

\subsection{Reliability tests}

Reliability test was conducted on each variable to identify the reliability of the items measuring them. None of the items of each variable were dropped as the results are satisfying which comparable to alpha value of greater than 0.70 as suggested by Hair et al. (2010). Table 2 illustrated the results for reliability tests.

Table 2. Results of Reliability Tests

\begin{tabular}{lccc}
\hline Variable & Number of Item & Items Dropped & Cronbach's Alpha \\
\hline Health Consciousness & 3 & - & ${ }^{* *} 0.858$ \\
Environmental attitude & 5 & - & ${ }^{* *} 0.808$ \\
Environmental knowledge & 3 & - & ${ }^{* *} 0.70$ \\
Environmental labelling on product & 4 & - & ${ }^{* *} 0.852$ \\
Green purchase intention & 4 & - & ${ }^{*} 0.875$ \\
\hline
\end{tabular}

*using 5 point Likert scale (very unlikely yes to very likely yes)

**using 7 point Likert scale (completely disagree to completely agree)

\subsection{Correlation analysis and normality test}

Correlation analysis was conducted to describe the degree of relationship between two variables. It is used to describe the direct relationship between the variables where a positive correlation indicates range from 0 to 1 . A positive correlation established shows that as one variable increases, the other variable also increases (Field, 2009). Kurtosis for each variable was reported both positive and negative, where the range was between \pm 3.29 while skewness falls within the range of \pm 2.58 at 0.01 significance level. The negative values of skewness indicated a higher scores whereas negative values of kurtosis shows a flatter shape of graph (Field, 2009:139). Table 3 shows the results of correlation 
analysis where each pair of correlations is significantly correlated at 0.01 level. Mean range between 3.811 and 6.201, implying that respondents rated agree on a 7 point Likert scale (completely disagree to completely agree).

Table 3. Correlation Analysis

\begin{tabular}{lccccc}
\hline Variable & 1 & 2 & 3 & 4 & 5 \\
\hline (1) Green purchase intention & 1 & & & & \\
(2) Health consciousness & $0.319^{*}$ & 1 & & & \\
(3) Environmental attitudes & $0.349^{*}$ & $0.387^{*}$ & 1 & & \\
(4) Environmental labelling on product & $0.147^{*}$ & $0.268^{*}$ & $0.235^{*}$ & 1 & \\
(5) Environmental Knowledge & $0.324^{*}$ & $0.323^{*}$ & $0.346^{*}$ & $0.145^{*}$ & 1 \\
\hline Mean & 3.811 & 5.639 & 6.201 & 5.714 & 4.847 \\
Standard Deviation & 0.802 & 0.967 & 0.942 & 0.988 & 1.183 \\
\hline Skewness & -0.19 & -0.563 & -1.186 & -0.494 & -0.515 \\
Kurtosis & -0.37 & -0.326 & 1.173 & 0.732 & -0.239 \\
\hline
\end{tabular}

${ }^{*}$ Correlation significant at the 0.01 level (2-tailed)

\subsection{Hypotheses testing}

Multiple regression analysis was conducted to test the relationship between the independent variables (health consciousness, environmental attitude, eco-labelling, environmental knowledge) and dependent variable (green purchase intention). Table 4 enumerates that the $\mathrm{R}^{2}=0.191(\mathrm{~F}=23.974, p<0.05)$. The results suggested that all four independent variables have explained the green purchase intention at $19 \%$. Environmental attitude stands out as the most significant factor in influencing Malaysian consumers' intention to purchase green product $\left(\beta_{2}=0.209, p .005\right)$. Hence, H2 is supported. Meanwhile, Health Consciousness was the second important factor that affects respondent's intention to purchase green product $\left(\beta_{1}=0.171\right.$, p0. 05$)$. H1 is sustained. Similarly, Environmental Knowledge also affected consumers' intention to purchase green product, posited a standardized coefficient beta value of 0.167 with $p<0.05$. Therefore, $\mathrm{H} 4$ is accepted, whereas Eco-labelling was found insignificant as the $p=0.364$ with standardized beta coefficient value of 0.043 and $p<.005$, thus rejecting $\mathrm{H} 3$.

Table 4. Multiple Regression Results

\begin{tabular}{lccccc}
\hline & \multicolumn{3}{c}{ Standardized Coefficients } & & \multicolumn{2}{c}{ Collinearity Statistics } \\
\hline & Beta & $\mathrm{t}$ & Sig. & Tolerance & VIF \\
\hline Health consciousness & 0.171 & 3.375 & $0.001^{*}$ & 0.774 & 1.292 \\
Environmental attitude & 0.209 & 3.968 & $0.000^{*}$ & 0.720 & 1.390 \\
Environmental labelling on product & 0.043 & 0.909 & 0.364 & 0.893 & 1.120 \\
Environmental knowledge & 0.167 & 3.344 & $0.001^{*}$ & 0.802 & 1.247 \\
\hline Multiple R ${ }^{2}$ & 0.191 & & & & \\
Adjusted R & 0.183 & & & & \\
F value & 23.974 & & & & \\
Sig. F & 0.000 & & & &
\end{tabular}

\section{Discussion}

This study determined the factors that lead Malaysians towards their intention to purchase greener products. Empirical results via multiple regressions, as illustrated in Figure 2, revealed that environmental attitude was the most significant factor influencing the consumers' green purchase intention among other factors. Attitude played an important role in putting consumers' mind-set into a positive attitude towards ethical consumption. Besides, the study also shown that a person who accounted health as important matter in their lives and with high level of consciousness of their health conditions have stronger intention to choose greener product as their choice of purchasing. These are the type of consumers who are not just concern for the environmental issues, health matters and have strong knowledge on the environmental issues which have a great potential as the green consumers.

Eco-labelling though was an important sign as symbol of assurance for a product to be safe for personal consumption and friendlier to the environment, but the results suggested that there is still lack of awareness and 
understanding among consumers regarding the meaning of eco-label (see Figure 2). As suggested by Rashid (2009), this study also implies that there is a need to improve the level of awareness on eco-labelling among Malaysian consumers as the higher level of eco-label awareness influence a better perception on the product reliability and hence, create a positive intention towards consuming greener products.

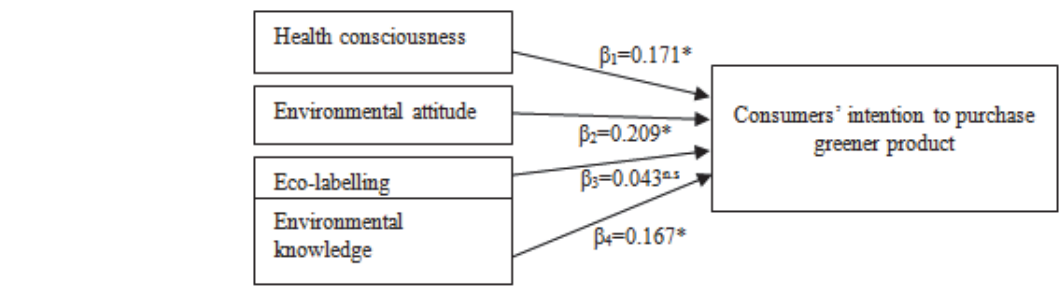

*Significance at $p<0.05 ;$ n.s = not significant

Figure 2. Results of Proposed Hypotheses

\section{Conclusion and Recommendations}

Eco-label is an essential tool to win the interest of consumers for green products. A certification that requires a certain procedures, quality and safety of a product is an assurance for consumers to trust the product's benefits. Despite educating consumers about the remarkable value of green products, consumers are still lacking in recognizing the label and meaning of the certification. It is important for consumers to know the meaning of the logo and the benefits of products with green certification so that consumers become more open to accept the existence of green-labelled products in the market, given that it was certified safe for human and environment by one of the government agencies.

Significant studies have shown that consumers are willing to pay a premium price for greener products (i.e. D'Souza et al., 2004; Laroche et al., 2001). However the findings from the empirical research is not adequate to convince more companies to invest more capital in acquiring new technologies, to improve the quality and safety of the ingredients or materials, to invest in introducing a greener product into the market or to get their products certified with eco-label. Educating consumers about the seriousness of environmental problems is crucial not just to promote sustainable environment, but also to create a healthier lifestyles. Environmental labelling or eco-labelling is a worth issue to be studied. This study has shown that respondents understanding and awareness on ecolabel need more improvement. Future research may further seek more evidence related to the government policies, companies' perceptions and responses as well as consumers perceptions towards various eco-labels in Malaysia.

\section{References}

Beardshaw, S. (1992). Economics: A student's guide. London: Pitman.

Becker, M., Maiman, L., Kirscht, J., Haefner, D., \& Drachman, R. (1977). The health belief model and prediction of dietary compliance: A field experiment. Journal of Health and Social Behaviour, 18(4), 348-366.

Cabrita, M. D. R., \& Bontis, N. (2008). Intellectual capital and business performance in the Portuguese banking industry. International Journal of Technology Management, 43(1-3), 212-237.

Chan, R. Y. K., \& Lau, L. B. Y. (2000). Antecedents of green purchases: A survey in China. Journal of Consumer Marketing, 17(4), 338357.

Chen, T. B., \& Chai, L. T. (2010). Attitude towards the environment and green products. Management Science and Engineering, 4(2), 27-33.

Dawes, J. (2008). Do data characteristics change according to the number of scale points used? An experiment using 5-point, 7-point and 10-point scales. International Journal of Market Research, 50(1), 61-78.

D'Souza, C. (2004). Ecolabel programmes: A stakeholder (consumer) perspective. Corporate Communications: An International Journal, 9(3), 177-188.

D'Souza, C., Taghian, M., \& Lamb, P. (2006). An empirical study on the influence of environmental labels on consumers. Corporate Communications: An International Journal, 11(2), 162-173.

Field, A. (2009). Discovering statistics using SPSS. (3rd ed.). London: Sage Publications Limited.

Hair, J. F. Jr., Lukas, B. A., Miller, K. E., Bush, R. P., \& Ortinau, D. J. (2008). Marketing Research (2nd ed.). Australia: McGraw Hill.

Hair, J. F., Black, B., Babin, B., Anderson, R. E., \& Tatham, R. L. (2010). Multivariate data analysis: A global perspective. New Jersey: Pearson Education Inc. 
Haron, S., Paim, L. \& Yahaya, N. (2005). Towards sustainable consumption: An examination of environmental knowledge among Malaysians. International Journal of Consumer Studies, 29(5), 426-436.

Ismail, H., \& Panni, M. F. A. K. (2008). Consumers perceptions on the consumerism issues and their influence on their purchasing behaviour: A view from Malaysian food industry. Journal of Legal, Ethical and Regulatory Issues, 11(1), 43-64.

Kim, Y., \& Choi, S. M. (2005). Antecedents of green purchase behaviour: An examination of collectivism, environmental concern, and PCE. Advances in Consumer Research, 32(1), 592-599.

Laroche, M., Bergeron, J., \& Barbaro-Forleo, G. (2001). Targeting consumers who are willing to pay more for environmentally friendly products. Journal of Consumer Marketing, 18(6), 503-520.

Laskova, A. (2007). Perceived consumer effectiveness and environmental concerns. Proceedings of the 13th Asia Pacific Management Conference, Melbourne, Australia, 206-209.

Lee, K. (2008). Opportunities for green marketing: Young consumers. Marketing Intelligence \& Planning, 26(6), 573-586.

Ottman, J. (2011). The new rules of green marketing. San Francisco, California: Berrett-Koehler Publishers.

Peattie, K., \& Peattie, S. (2009). Social marketing: A pathway to consumption reduction?. Journal of Business Research, 62(2), $260-268$.

Pickett-Baker, J., \& Ozaki, R. (2008). Pro-environmental products: Marketinginfluence on consumer purchase decision. Journal of Consumer Marketing, 25(5), 281-293.

Rashid, N. R. N. A. (2007). Employee involvement in EMS/ISO 14001 and its spillover effect in creating consumer environmentally responsible behaviour (PhD Thesis, Universiti Sains Malaysia, 2007).

Rashid, N. R. N. A. (2009). Awareness of eco-label in Malaysia's green marketing initiative. International Journal of Business and Management, 4(8), 132-141.

Sekaran, U. (2009). Research methods for business: A skill building approach (4th ed.). India: Wiley India Publishing Ltd.

Shaharudin, M. R., Pani, J. J., Mansor, S. W., Elias, S. J., \& Sadek, D. M. (2010). Purchase intention of organic food in Kedah, Malaysia: A religious overview. International Journal of Marketing Studies, 2(1), 96-103.

Sinnappan, P., \& Rahman, A. A. (2011). Antecedents of green purchasing behaviour among Malaysian consumers. International Business Management, 5(3), 129-139.

Statistics.gov.my (2013). Department of Statistics Official Website. [Online] Available: http://www.statistics.gov.my/portal (August 11, 2013).

Statistics Malaysia. (2010). Population distribution and basic demographic characteristic population cencus of Malaysia. Department of Statistics Malaysia, Kuala Lumpur.

Tan, A., Dunn, R., Samad, M., \& Feisul, M. (2011). Sociodemographic and health-lifestyle determinants of obesity risks in Malaysia. Asia-Pacific Journal of Public Health, 23(2), 192-202. 